Submitted, accepted and published by:

International Journal of Greenhouse Gas Control (2013) Vol. 19, pp. 322-330

\title{
Biomass combustion in a CLC system using an iron ore as an oxygen carrier
}

T. Mendiara*, A. Abad, L. F. de Diego, F. García-Labiano, P. Gayán, J. Adánez

Department of Energy and Environment, Instituto de Carboquímica-ICB-CSIC

Miguel Luesma Castán 4, 50018, Zaragoza, Spain

tmendiara@icb.csic.es

* Corresponding author:

Phone: + 34976733 977;

Fax: +34976 733318 


\begin{abstract}
Chemical looping combustion (CLC) is a promising $\mathrm{CO}_{2}$ capture technology with a very low energy penalty and cost. Several previous studies have demonstrated the feasibility of this technology using both gaseous and solid fuels. The combustion of biomass using CLC would make the concept of negative- $\mathrm{CO}_{2}$ emission possible. This paper presents a study of biomass combustion in a continuous CLC unit using pine wood as fuel and iron ore as an oxygen carrier and analyses several parameters influencing the CLC process. High carbon captures (>95\%) were achieved in the interval $880-915^{\circ} \mathrm{C}$ using both steam and $\mathrm{CO}_{2}$ as gasifying agents. Tar compounds were detected at the fuel reactor outlet. After 78 hours of continuous operation, no changes were detected in the physical and chemical properties of the oxygen carrier particles.
\end{abstract}

Keywords: combustion, biomass, $\mathrm{CO}_{2}$ capture, chemical looping, iron ore 


\section{Introduction}

Reducing carbon dioxide emissions has currently become one of the main environmental concerns, as the increase in $\mathrm{CO}_{2}$ levels in the atmosphere has been linked to increases in global temperature. Different solutions for $\mathrm{CO}_{2}$ emission reduction have emerged in recent years. One of the leading alternatives is Carbon Capture and Storage (CCS). CCS has the potential to reduce overall mitigation costs and increase flexibility in achieving greenhouse gas emission reductions (IPCC, 2005). CLC has emerged during the last years as a competitive option (Adánez et al., 2012) in the field of carbon capture. In a CLC system, an oxygen carrier transfers the necessary oxygen for combustion from the air to the fuel. The most common configuration is composed of two interconnected fluidized bed reactors, the air reactor and the fuel reactor. The oxygen carrier circulates between them. Fuel is introduced into the fuel reactor where it is converted by the oxygen carrier to produce $\mathrm{CO}_{2}$ and $\mathrm{H}_{2} \mathrm{O}$. The spent oxygen carrier must then be transported to the air reactor to be oxidized by air in order to start a new cycle. $\mathrm{CO}_{2}$ capture is inherent to this process, as the air is not mixed with the fuel. To date, the CLC concept has been successfully demonstrated for both gaseous and solids fuels, mainly coal (Adánez et al., 2012). Gaseous fuel combustion was reported in continuously operated units in the range of $120 \mathrm{~kW}_{\text {th }}$ (Kolbitsch et al., 2009).

Significant advances have been made in the development of CLC using solid fuels (mainly coal) in recent years, by means of both in situ gasification CLC ( $i \mathrm{G}-\mathrm{CLC})$ and Chemical Looping with Oxygen Uncoupling (CLOU) (Abad et al., 2012; Orth et al., 2012). $i \mathrm{G}-\mathrm{CLC}$ involves the fuel being fed directly into the fuel reactor and mixed with the oxygen carrier, as shown in Figure 1. Steam or $\mathrm{CO}_{2}$ are supplied to the fuel reactor 
as fluidizing agents. These gases also act as coal gasifying agents according to the following reaction scheme:

Coal $\rightarrow$ volatiles + char

$\mathrm{Char}+\mathrm{H}_{2} \mathrm{O} \rightarrow \mathrm{H}_{2}+\mathrm{CO}+$ ash

$\mathrm{Char}+\mathrm{CO}_{2} \rightarrow 2 \mathrm{CO}+$ ash

Char gasification has been identified as the limiting step of this process (Cuadrat el al., 2011; Mendiara et al., 2013). The oxygen carrier reacts with the gases produced in reactions (1)-(3) to produce $\mathrm{CO}_{2}$ and water as products. The most recent investigations in this respect were presented in a $100 \mathrm{~kW}$ continuous rig (Markström et al., 2013) and 1 MW thermal power (Orth et al., 2012). However, other solid fuels have received little coverage regarding their possibile use in a CLC system.

Biomass is an interesting fuel to be tested in CLC. If the carbon dioxide generated during biomass combustion could be captured, this would lead to negative $\mathrm{CO}_{2}$ emissions, as the $\mathrm{CO}_{2}$ released in combustion had previously been removed from the atmosphere during biomass growth. Some studies dealing with the CLC of biomass can be found in the literature. Some of them presented studies in a batch fluidized bed reactor (Jerndal et al., 2011; Leion et al., 2009; Leion et al., 2011). These studies made use of wood char as fuel and different low-cost, iron-based materials as oxygen carriers. Leion et al. (2009) observed a strong dependence of the wood char conversion on temperature. Char conversion rate values for $95 \%$ conversion of the fuel in the range 900-1000 ${ }^{\circ} \mathrm{C}$ oscillated between 3.4 and $23.5 \% / \mathrm{min}$, with increasing values for higher temperatures. These values were higher than those reported in the same study for petroleum coke and bituminous Colombian coal and lower than those observed for German lignite. 
Only a few studies were carried out in a continuous CLC unit using biomass as fuel (Shen et al., 2009; Gu et al., 2011). In both cases, the configuration used corresponded to $i \mathrm{G}-\mathrm{CLC}$. Shen et al. (2009) performed experiments in a $10 \mathrm{~kW}_{\text {th }}$ unit using pine sawdust and an oxygen carrier prepared from iron oxide powders. They tested the effect of fuel reactor temperature on gas composition in both fuel and air reactors. The proportion of biomass to carbon reacting in the fuel reactor and the conversion of biomass carbon to $\mathrm{CO}_{2}$ were also investigated. A spouted bed was adopted for the fuel reactor in order to avoid biomass segregation in the bed and elutriation of fine char particles. The fuel reactor temperature was varied from 740 to $920^{\circ} \mathrm{C}$ and recycled $\mathrm{CO}_{2}$ was used as the gasifying agent. They observed the presence of $\mathrm{CO}$ and $\mathrm{CH}_{4}$ as unburned species at the fuel reactor outlet, but no hydrogen was detected. Methane concentration was not significantly affected by temperature. However, $\mathrm{CO}$ concentration increased as the temperature in the fuel reactor increased. At the same time, the $\mathrm{CO}_{2}$ concentration at the air reactor outlet decreased with temperature, indicating that more biomass char was consumed in the fuel reactor at higher temperatures. Therefore, the proportion of biomass carbon reacting in the fuel reactor increased with temperature. However, no carbon capture values were given. On the other hand, the conversion of biomass carbon to $\mathrm{CO}_{2}$ in the fuel reactor decreased from $65.1 \%$ at $920^{\circ} \mathrm{C}$ to $53.7 \%$ at $740^{\circ} \mathrm{C}$. The increase in the fuel reactor temperature produced a higher increase in the $\mathrm{CO}$ production from biomass gasification than in the consumption of $\mathrm{CO}$ by the oxygen carrier to yield $\mathrm{CO}_{2}$. As a continuation of this work, Gu et al., 2011 presented a similar study in a $1 \mathrm{~kW}_{\text {th }}$ CLC system. The configuration of the CLC unit also used a spouted bed as a fuel reactor. Gu et al., 2011 used sawdust and sawdust/bituminous (1/1) coal mixtures as fuels. Steam was the gasifying agent 
supplied to the fuel reactor and an Australian iron ore was used as the oxygen carrier (81.1 wt $\% \mathrm{Fe}_{2} \mathrm{O}_{3}$ ). Similarly to Shen et al. (2009), they studied the influence of fuel reactor temperature on performance during the process. One of the important findings of their research was the difference between the experiments with pure biomass and biomass/coal mixtures, which were attributed mainly to fuel reactivity. Biomass contained a larger amount of volatiles compared to the bituminous coal used. This meant that temperature would not greatly affect the degree of gasification in the temperature range tested $\left(720-980^{\circ} \mathrm{C}\right)$. In the case of biomass, fuel conversion would become more limited by the reaction between gasification products and the oxygen carrier particles. Nevertheless, whatever the fuel used, the carbon capture efficiency increased with temperature, reaching values close to $99 \%$ at $980^{\circ} \mathrm{C}$, the highest temperature tested. Another significant finding was the deposition of alkali metals from biomass ash on the surface of the oxygen carrier particles without influencing the reactivity of the oxygen carrier in this case.

The aim of the present work was to investigate biomass combustion further in an $i \mathrm{G}-$ CLC system consisting of two interconnected fluidized bed reactors. This configuration is more common than the spouted bed previously used. A comprehensive study of the influence on the $i \mathrm{G}-\mathrm{CLC}$ performance of most of the main variables of the process was performed using an iron ore as an oxygen carrier. The effect of operating conditions such as the fuel reactor temperature, solid circulation rate and gasifying agent on carbon capture efficiency and the oxygen demand was analysed. Moreover, the presence of tar from biomass pyrolysis in the fuel reactor outlet was studied for the first time. The amount and type of tar compounds was determined at different temperatures. 


\section{Experimental}

\subsection{Biomass and oxygen carrier used}

Pine sawdust (Pinus Sylvestris) from Spain was used in the experiments as fuel.

Particles were sieved to $0.5-1 \mathrm{~mm}$ size. Table 1 shows the proximate and ultimate analyses of the biomass, together with the low heating value (LHV). An iron ore from a hematite mine in Tierga (province of Zaragoza, Spain) was supplied by PROMINDSA. The fraction with a size $>500 \mu \mathrm{m}$ was crushed and sieved to the desired size $(+100-300$ $\mu \mathrm{m})$. The main solid phases identified by XRD diffraction were hematite $\left(\mathrm{Fe}_{2} \mathrm{O}_{3}\right)$, dolomite $\left(\mathrm{CaMg}\left(\mathrm{CO}_{3}\right)_{2}\right)$ and $\mathrm{SiO}_{2}$. It was then calcined at $950^{\circ} \mathrm{C}$ for 12 hours, in order to decompose the dolomite impurities present in the sample to $\mathrm{CaO}$ and $\mathrm{MgO}$, and to increase mechanical strength. The resulting material was used as the oxygen carrier. The main chemical and physical properties of the calcined material are shown in Table 2. Details regarding the characterization of this oxygen carrier can be found elsewhere (Mendiara et al., 2012).

\subsection{Experimental setup and procedure}

The biomass combustion experiments were performed at the ICB-CSIC-s1 unit (Figure 2). This experimental unit comprised two interconnected fluidized bed reactors, (1) and (3) in Figure 2, heated by electric furnaces (11). The fuel reactor (FR) (1) and the air reactor (AR) (3) were connected by a fluidized bed acting as loop seal (2). A riser (4) transported solids from the air to the fuel reactor. A cyclone recovered the entrained solids (5) and a solids valve controlled the solids flow fed to the fuel reactor. The fuel reactor consisted of a bubbling fluidized bed (50 mm ID). Biomass was fed by means of a screw feeder (9) at the bottom of this bed and just above the fuel reactor distributor plate. The fuel reactor was fluidized by steam or $\mathrm{CO}_{2}$ as gasifying agents. The reduced 
oxygen carrier particles overflowed through a U-shaped fluidized bed loop seal that was fluidized using nitrogen (50 $\mathrm{mm} \mathrm{ID)} \mathrm{to} \mathrm{the} \mathrm{air} \mathrm{reactor,} \mathrm{preventing} \mathrm{the} \mathrm{mixing} \mathrm{of} \mathrm{gaseous}$ atmospheres between the fuel and air reactors. Preliminary results showed that about $65 \%$ of this nitrogen reached the fuel reactor and the rest went to the air reactor. The reduced oxygen carrier and unconverted char particles were oxidized in the air reactor (80 $\mathrm{mm}$ ID). Secondary air was introduced at the top of the bubbling bed to help particle entrainment. The outlet stream from the air reactor was sent up the riser to the stack through a high efficiency cyclone and filter. A diverting solid valve (6) enabled the measurement of the solid flow rates to be taken at any time.

This design could allow unconverted char particles to be transported together with the oxygen carrier to the air reactor. To prevent this loss of carbon, a carbon stripper could be placed after the fuel reactor in an industrial CLC facility (Cao et al., 2006). In fact, a carbon stripper is one of the best options to maximize carbon capture in the CLC of solid fuels (Kramp et al., 2012; Markström et al., 2013; Abad et al., 2013). However, the absence of a carbon stripper in this unit facilitated interpretation of the effect of different operating conditions on the results obtained.

The oxygen carrier inventory was $3.6 \mathrm{~kg}$. The solid level in the fuel reactor was fixed, corresponding to $0.7 \mathrm{~kg}$ of the mineral based on hematite. The biomass feed rate was 95 $\mathrm{g} / \mathrm{h}$. The steam flow to the fuel reactor corresponded to a velocity of $0.1 \mathrm{~m} / \mathrm{s}$ at $900^{\circ} \mathrm{C}$. The total primary air flow in the air reactor was $2250 \mathrm{~L}_{\mathrm{N}} / \mathrm{h}$ (corresponding to a velocity of $0.5 \mathrm{~m} / \mathrm{s}$ at $\left.900^{\circ} \mathrm{C}\right)$. The secondary air flow was $680 \mathrm{~L}_{N} / \mathrm{h}$. Taking both primary and secondary air flows into consideration, the riser gas velocity was $2 \mathrm{~m} / \mathrm{s}$. The oxygen carrier to fuel ratio $(\phi)$ defined the conditions under which the experiments were performed. The oxygen carrier to fuel ratio is a measure of how much oxygen can be 
supplied by the circulating oxygen carrier compared to the oxygen needed to burn the fuel fed into the system. Stoichiometric conditions are represented by an oxygen carrier to fuel ratio equal to one.

$\phi=\frac{F_{O C} \cdot R_{O C}}{\Omega_{S F}}$

A total of 37 hours of continuous operation feeding fuel and 78 hours of continuous fluidization were registered. $\mathrm{CO}, \mathrm{CO}_{2}, \mathrm{H}_{2}$ and $\mathrm{CH}_{4}$ concentration in the fuel reactor outlet stream together with $\mathrm{CO}, \mathrm{CO}_{2}$ and $\mathrm{O}_{2}$ from the air reactor were recorded. The presence of higher hydrocarbons was also tested using sampling bags. The samples were taken at the fuel reactor outlet and analysed by means of gas cromatography. The samples were analysed in an HP 5890 gas chromatograph (GC) equipped with a TCD detector. The amount of tar present in fuel reactor product gases was also determined following the tar protocol (Simell et al., 2000). For one hour, the fuel reactor gas flowed through two impingers at $0^{\circ} \mathrm{C}$ and through another six at $-18^{\circ} \mathrm{C}$, so that both moisture and tar could be collected by absorption in isopropanol. The quantitative determination of the concentrations of the different tar compounds in the samples was determined by a GC (Agilent 7890A) fitted with a capillary column (HP-5) and FID detector. Furthermore, the GC was coupled with a mass spectrometer (Agilent 5975C).

\subsection{Data evaluation}

Two main parameters were defined in order to evaluate the performance of the fuel reactor: carbon capture efficiency and oxygen demand. Carbon mass balances closed within $90 \%$. The difference between the carbon present in both the fuel and air reactor exhaust gases and the carbon in the introduced biomass revealed that elutriation of char took place in the fuel reactor. All the calculations presented hereafter considered the effective char fed to the system. Thus, the carbon balance took into account the carbon 
exiting the fuel reactor as gaseous compounds and the carbon in the char transported to the air reactor and burned to yield $\mathrm{CO}_{2}$.

Carbon capture efficiency $\left(\eta_{C C}\right)$ represents the removal of carbon that would otherwise be emitted to the atmosphere and is defined as the fraction of the carbon introduced which is converted to gas inside the fuel reactor. Only $\mathrm{CH}_{4}, \mathrm{CO}$ and $\mathrm{CO}_{2}$ were considered, as the amount of tars and hydrocarbons heavier than $\mathrm{CH}_{4}$ was negligible.

$\eta_{C C}=\frac{\left[F_{C O_{2}, F R}+F_{C O, F R}+F_{C H_{4}, F R}\right]_{\text {out }}-\left[F_{C O_{2}, F R}\right]_{\text {in }}}{\left[F_{C O_{2}, F R}+F_{C O, F R}+F_{C H_{4}, F R}+F_{C O_{2}, A R}\right]_{\text {out }}-\left[F_{C O_{2}, F R}\right]_{\text {in }}}$

where $F_{i, F R}$ is the $i$ species molar flow in the fuel reactor inlet/outlet stream. For the experiments using $\mathrm{CO}_{2}$ as fluidization agent, the inlet $\mathrm{CO}_{2}$ flow must be subtracted. $F_{C_{2}, A R}$ is the $\mathrm{CO}_{2}$ gas flow at the air reactor outlet.

The carbon captured in the system comprised the carbon contained in the volatiles and the carbon in the char that was gasified. Thus, carbon capture efficiency depended on the fraction of char that has been gasified. Char conversion $\left(X_{\text {char }}\right)$ is defined as the fraction of carbon in the effective char fed to the fuel reactor which was released into the fuel reactor exhaust gas stream:

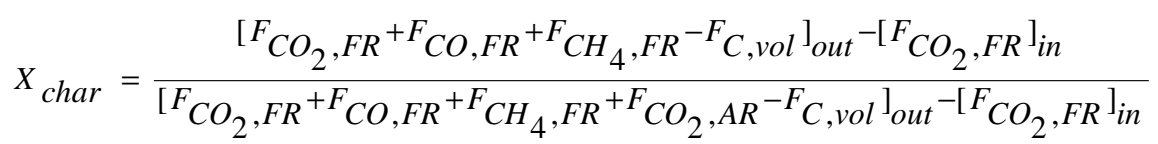

The gasified char in the fuel reactor was calculated as difference between the carbon in the outlet gases of the fuel reactor and the carbon flow coming from the volatile matter, $F_{C \text {,vol }}$. The carbon content in the volatiles was directly calculated using the ultimate and proximate analysis of the biomass as the difference between the total carbon in biomass and the fixed carbon.

Oxygen demand $\left(\Omega_{T}\right)$ refers to the oxygen needed to convert unburned compounds and $\operatorname{tar}\left(\mathrm{C}_{\mathrm{x}} \mathrm{H}_{\mathrm{y}} \mathrm{O}_{\mathrm{z}}\right)$ in the outlet gas from the fuel reactor to $\mathrm{CO}_{2}$ and $\mathrm{H}_{2} \mathrm{O}$. This parameter 
therefore evaluates the efficiency of the combustion process (Kempkes and Kather, 2012) and is defined as the fraction of oxygen lacking in order for the complete combustion to $\mathrm{CO}_{2}$ and $\mathrm{H}_{2} \mathrm{O}$ of the fuel reactor product gas to be achieved in comparison to the oxygen demand of the introduced biomass, $O_{2_{\text {demand }} \text {,biomass }}$.

$$
\Omega_{T}=\frac{0.5 \cdot F_{C O, F R}+2 \cdot F_{C H_{4}, F R}+0.5 \cdot F_{H_{2}, F R}+(x+y / 4-z / 2) \cdot F_{C_{x} H_{y} O_{z}}}{O_{2_{\text {demand }} \text { biomass }}}
$$

The mean residence time of the oxygen carrier particles was also estimated assuming a low amount of char and ash present in the fuel reactor and perfect mixing of the oxygen carrier particles:

$$
t_{m, O C}=\frac{m_{O C, F R}}{F_{O C}}
$$

If there were no char elutriation in the fuel reactor, the residence time of the oxygen carrier and the char particles would be the same, but as some char particles may escape from the bed, the residence time of the char particles would be somewhat lower. This value was calculated as the mass of char in the fuel reactor, $m_{c h a r, F R}$, divided by the char flow exiting the fuel reactor, which was the sum of carbon in the elutriated particles $C_{c h a r, e l u t r}$ and the carbon flow from the char to the air-reactor $C_{c h a r, A R}$.

$$
t_{m, \text { char }}=\frac{m_{\text {char }, F R}}{C_{\text {char }, A R}+C_{\text {char }, \text { elutr }}}
$$

The rate of char conversion, $\left(-r_{C}\right)$, was calculated assuming the fuel reactor as a continuous stirred tank reactor.

$$
\frac{F_{C O_{2}, A R}}{F_{C, \text { chareff }}}=\frac{1}{\left(-r_{C}\right) \cdot t_{m, \text { char }}+1}
$$




\section{Results and Discussion}

\subsection{Effect of temperature}

\subsubsection{Composition of the gas at the fuel reactor outlet}

The composition of the gas at the outlet of the fuel reactor was analysed at the different temperatures studied. In all cases, the main gaseous products found were $\mathrm{CO}_{2}, \mathrm{CO}, \mathrm{H}_{2}$ and $\mathrm{CH}_{4}$. Figure 3(A) shows the evolution of the concentration (dry $\mathrm{N}_{2}$ free) of these gases with temperature. $\mathrm{CO}_{2}$ was the major product and its concentration increased with temperature from $80 \%$ at $880^{\circ} \mathrm{C}$ up to $93 \%$ at $915^{\circ} \mathrm{C}$. The concentration of the rest of the gases decreased with temperature. Most of them were generated during biomass devolatilization. According to the values shown in Table 1, the amount of volatiles released by biomass corresponded to $80 \mathrm{wt} . \%$, therefore, the iron ore particles in the fuel reactor faced a significant amount of gases with which to react. The reactivity of the iron ore to $\mathrm{CO}, \mathrm{H}_{2}$ and $\mathrm{CH}_{4}$ was analysed in a previous work by the authors (Mendiara et al., 2012). The fastest reaction was observed between the iron ore particles and hydrogen, followed by the reaction with $\mathrm{CO}$ and finally with $\mathrm{CH}_{4}$. For any of these gases, the reactivity increased with temperature, which would explain the reduction of their presence with temperature. Nevertheless, $3.8 \% \mathrm{CO}, 1.7 \% \mathrm{H}_{2}$ and $1.1 \% \mathrm{CH}_{4}$ were found at the fuel reactor outlet at $915^{\circ} \mathrm{C}$.

However, other compounds can be generated during the devolatilization of biomass, such as hydrocarbons heavier than methane. These hydrocarbons can react in the fuel reactor with the iron ore particles or be reformed by steam. After reaching stable operating conditions at different temperatures, several samples were taken from the outlet stream of the fuel reactor using sampling bags. No presence of $\mathrm{C}_{2}-\mathrm{C}_{4}$ 
hydrocarbons was detected in any of the analyses performed. Therefore, these compounds were completely burned/reformed in the fuel reactor.

Besides the large production of volatiles, significant amount of tar compounds can be generated during wood biomass gasification compared to coal (Diebold et al., 1994). In order to study the fate of the tar compounds generated during biomass combustion in the CLC unit, samples were taken at different temperatures according to the tar protocol (Simell et al., 2000). Figure 3 (A) also shows the evolution of the tar content in the gas, in $\mathrm{g} / \mathrm{Nm}^{3}$ of dry gas. The presence of the tar compounds in the fuel reactor exit decreased with temperature from a value of 1.38 to $0.2 \mathrm{~g} / \mathrm{Nm}^{3}$. The amounts detected were lower than those referenced for pine sawdust gasification in a fluidized bed using olivine or Fe/olivine catalysts for tar destruction in similar experimental conditions (Virginie et al., 2012). In the experiments using Fe/olivine catalyst, the tar reduction percentage estimated was $0.59 \%$ per Celsius degree in the interval $800-850^{\circ} \mathrm{C}$. However, in the present experiments, the reduction percentage was $2.4 \%$ per Celsius degree, almost five times that obtained with Fe/olivine, which indicates that tars are capable of reacting with iron ore particles. The tar content in the fuel reactor exhaust gas may have implications regarding further steps in the CCS chain, i.e. compression, transport and storage. The quality of the $\mathrm{CO}_{2}$ captured is still a subject of debate. To date, only a limited number of recommendations for $\mathrm{CO}_{2}$ transport and storage have been given by industry (Pipitone and Bolland, 2009). According to those guidelines, the hydrocarbon content of the $\mathrm{CO}_{2}$ stream should not exceed 5\%, but no further indications have been given as to the nature of those hydrocarbons. Nevertheless, considering the experience gained in the field of biomass gasification for power generation, operational problems may be anticipated if the tar concentration is high. Tar condenses easily, and 
this property is known to cause fouling in pipes, filter elements and heat exchangers. When condensing, tar may also polymerize to form more complex structures and therefore increase the chance of causing blockages. To prevent these problems, most power applications have limited the maximum tar content in the gaseous stream used as fuel (Bridgwater, 1995; Milne et al., 1998). Of special interest is the limit value given by Reed et al. (1987) for compressing and piping any distance a biomass gasification gas. According to this study, the tar content should be in the range of $0.05-0.5 \mathrm{~g} / \mathrm{Nm}^{3}$. If this interval had been taken as reference, the tar content in the outlet gas from the fuel reactor in the present work would have been too high, except for the experiment at $915^{\circ} \mathrm{C}$. Therefore, the tar content should be reduced before compression in an additional gas conditioning step. Alternatively, considering the tendency observed in Figure 3 (A), an increase in the fuel reactor temperature could also help to reduce the tar content in the product gas.

Evans and Milne (1987a,b) classified biomass pyrolysis products as primary, secondary and tertiary. Primary tars are mainly cellulose, hemicellulose or lignin derived products. Secondary tars are characterized by olefins and phenolics. Tertiary tars comprise methyl derivatives of aromatics (methylnaphthalene, toluene, indene and phenol) and PAHs without substituents (benzene, naphthalene, anthracene, phenanthrene and pyrene). Due to the increase in temperature, oxygenated tar compounds are converted to light hydrocarbons, aromatics, oxygenated and olefins, subsequently forming higher hydrocarbons and larger PAHs in tertiary processes (Milne et al., 1998). Heavier tars are more difficult to gasify, but they are produced in smaller quantities during biomass gasification when compared to coal gasification. The composition of the tars measured in the biomass CLC was analysed and the results are presented in Figure 3 (B). Only 
three tar compounds were identified at the three temperatures tested: styrene, indene and naphthalene. All of them could be classified as tertiary tars. At the lowest temperature tested, most of the tar recovered was naphthalene. However, the amount of naphthalene in the tar decreased dramatically as temperature increased. The levels of indene and styrene also tended to decrease with temperature. It seems that high temperature favoured both the reforming of these compounds and/or their reaction with the iron ore particles.

\subsubsection{Carbon capture efficiency and oxygen demand}

The main parameters used to analyse the biomass CLC are shown in Figure 4 (A). The most significant results are the high carbon captures obtained, which reached $97.5 \%$ at $915^{\circ} \mathrm{C}$. The carbon capture efficiency did not change significantly with temperature and the values were notably higher than those registered for coal combustion in this unit. As a reference for comparison, a number of experiments using this same iron ore as an oxygen carrier and anthracite as fuel were performed in the same experimental system. In this case, carbon capture efficiencies ranged from 30 to $45 \%$ in the same temperature interval $\left(880-915^{\circ} \mathrm{C}\right)$. Using ilmenite or a bauxite waste as oxygen carriers and a bituminous coal with high volatile content (HVB) as fuel, carbon capture efficiencies of between 45 and 60\% were obtained (Cuadrat et al., 2012; Mendiara et al., 2013). The highest carbon capture efficiencies in this experimental unit were achieved using ilmenite and lignite as fuel. Those values oscillated between $85-93 \%$ in the same temperature interval, but they were still lower than those recorded for biomass in the present work. This is due to the fact that the amount of volatiles in biomass is larger than in most of the coals, particularly anthracite. As previously mentioned, carbon capture is defined as the fraction of the introduced carbon converted to gas in the fuel 
reactor. So, if a large proportion of the carbon is released as volatiles in the fuel reactor, carbon capture will be higher for biomass. At the same time, less char will be formed. As mentioned earlier, the char gasification step is the limiting step of the process in this technology. Furthermore, biomass char has shown to be more reactive than coal char. So if less char is produced and it presents a higher gasification rate, carbon capture will increase compared to the case of coal combustion. In the experiments shown in Figure 4 (A) the values of char conversion reached ranged between $74 \%$ at $880^{\circ} \mathrm{C}$ and $84 \%$ at $915^{\circ} \mathrm{C}$, much higher than when using this same oxygen carrier and anthracite, for which values between 29 and $40 \%$ were obtained. The char conversion values obtained in experiments with biomass are also higher than those reported in the same temperature interval using ilmenite or the bauxite waste and a HVB coal, where char conversion in the $20-40 \%$ range was recorded. Char conversion values varied between 78 and $87 \%$ when ilmenite and lignite were used. The rate of char gasification at different temperatures was calculated and is shown in Figure 4 (B). Biomass char gasification rates increased from $37.2 \% / \mathrm{min}$ at $881^{\circ} \mathrm{C}$ to $57.6 \% / \mathrm{min}$ at $915^{\circ} \mathrm{C}$. In comparison, Figure 4 (B) also includes the char conversion rates for different coals under similar experimental conditions in the same continuous unit using other low-cost Fe-based oxygen carrier materials (Cuadrat et al., 2012; Mendiara et al., 2013). In the experiments with this iron ore and anthracite, the char conversion rate ranged between 2 and $4.2 \% / \mathrm{min}$, which is almost 15 times lower than those corresponding to biomass char. Mendiara et al. (2013) used a highly-reactive bauxite waste residue in the combustion of a bituminous Colombian coal and obtained a char gasification rate of 19.2\%/min at $930^{\circ} \mathrm{C}$. Cuadrat et al. (2012), tested ilmenite, a mineral based on $\mathrm{FeTiO}_{3}$, in the combustion of a Spanish lignite and a South African bituminous coal with 
medium volatile content (MVB). At $900^{\circ} \mathrm{C}$, they reported a char gasification rate of $31.0 \% / \mathrm{min}$ for lignite and 3.1\%/min for the MVB. The higher the char gasification rate, the higher the extent of char consumption in the fuel reactor, and therefore the less carbon that reaches the air reactor transported by the oxygen carrier particles and the higher the carbon capture efficiencies that can be obtained. In order to increase the residence time of the char particles in the fuel reactor and to improve char conversion, a carbon separation unit can be used. This unit separates unconverted char particles from the oxygen carrier and returns them to the fuel reactor. As shown earlier, in the case of using biomass as fuel, carbon capture efficiencies are already high without using a carbon separation unit. If this unit were to be implemented in a CLC system, biomass combustion could reach carbon capture efficiencies close to $100 \%$, as it has been demonstrated in other CLC units using coal (Markström et al., 2013).

The third parameter shown in Figure 4 (A) is oxygen demand. Compared to the oxygen needed by the unburned compounds at the fuel reactor outlet stream, the oxygen consumed by the tar was considered negligible and therefore not included in the calculation of the oxygen demand. The value of this parameter decreased with temperature as the reactivity of the iron ore particles also increased with temperature, from $14.1 \%$ at $880^{\circ} \mathrm{C}$ to $3.8 \%$ at $915^{\circ} \mathrm{C}$. Nevertheless, these values were only slightly higher than those obtained with coal in similar conditions. In experiments with a lowvolatile coal such as anthracite, the oxygen demand at $880^{\circ} \mathrm{C}$ was $3.7 \%$. This is again a consequence of the large amount of volatiles released during biomass devolatilization compared to coal. If more gases are produced, there could be worse contact between these gases and the iron ore particles and therefore some of them could escape unconverted, increasing oxygen demand. 


\subsection{Effect of the gasifying agent}

One of the advantages of the CLC technology compared to other carbon capture technologies is the low cost of the $\mathrm{CO}_{2}$ captured. The cost estimated for the capture of one tonne $\mathrm{CO}_{2}$ using CLC is 6-13 $€$ (Ekström et al., 2009). In order to decrease the cost of CLC of solid fuels further, it would be interesting to use recirculated $\mathrm{CO}_{2}$ instead of steam as the gasifying agent, to save on the energy consumption associated with steam generation. The experience gained in the study of CLC of coal indicated that the use of $\mathrm{CO}_{2}$ in the gasifying mixture should be limited, especially for high-rank coals, in order to maintain high carbon capture efficiency. Char gasification rate with $\mathrm{CO}_{2}$ is lower than that observed under similar conditions using steam and this causes carbon capture to decrease (Cuadrat et al., 2012; Mendiara et al., 2013). However, as mentioned earlier, biomass char has proved to be more reactive than char from coal; therefore, in this case, the decrease in the efficiency observed during the dry gasification of biomass could be acceptable. Experiments using either steam or $\mathrm{CO}_{2}$ were performed at $905^{\circ} \mathrm{C}$ and carbon capture efficiency, char conversion and oxygen demand values were then compared.

Carbon capture efficiency was not affected by the gasifying agent composition, remaining at around $97 \%$ in both cases. The extent of char conversion was similar, with a slightly higher value recorded for gasification with steam (84\% compared to $79 \%$ reached using $\mathrm{CO}_{2}$ ). Char gasification rates in the experiments with steam and $\mathrm{CO}_{2}$ were also calculated and resulted in $36.5 \% / \mathrm{min}$ and $30 \% / \mathrm{min}$, respectively. The reduction in the char gasification rate when $\mathrm{CO}_{2}$ was used as gasifying agent was small, which is a significant result. The use of $\mathrm{CO}_{2}$ also implies a reduction in the amount of steam present in the fuel reactor atmosphere, which can affect the reforming of the heavy hydrocarbons and tars generated during char gasification. Tar measurements were also 
conducted in the experiment with $\mathrm{CO}_{2}$ at $905^{\circ} \mathrm{C}$. The tar content in the outlet stream from the fuel reactor was $0.2 \mathrm{~g} / \mathrm{Nm}^{3}$, similar to that obtained at this temperature with steam as the gasifying agent $\left(0.29 \mathrm{~g} / \mathrm{Nm}^{3}\right)$, although in this case the major component in the tar was indene (40.6\%) followed by naphthalene and styrene. This seems to indicate that dry reforming of hydrocarbons may also take place and that the reaction of the hydrocarbons with the iron ore particles is also a significant contribution to the depletion of these species. Finally, insignificant differences were observed in oxygen demand values. In the experiment with steam, the oxygen demand was $7.2 \%$, while in the experiment with $\mathrm{CO}_{2}$, the oxygen demand observed was $6.4 \%$.

It can be concluded that no significant changes in the performance of the process were found when $\mathrm{CO}_{2}$ replaced steam as the gasifying agent in CLC with biomass. Therefore it is possible to use dry recirculated $\mathrm{CO}_{2}$ as feed in the fuel reactor, which is an important advantage for the progress of this technology.

\subsection{Effect of the solids circulation rate}

After the analysis of the effect of temperature and the composition of the gasifying agent on CLC of biomass, the influence of the solids circulation rate on the combustion performance was investigated. The increase in the solid circulation rate increases the average reactivity of the oxygen carrier particles (Abad et al., 2007a) but decreases the residence time of char particles in the fuel reactor therefore affecting the carbon capture efficiency of the CLC process. From previous works with coal, it was already known that this effect is deeper for values of fuel-to oxygen carrier $(\phi)$ ratios lower than unity and it is attenuated for high $\phi$ values (Cuadrat et al., 2012; Mendiara et al., 2013). In the case of CLC of biomass, owing to the high reactivity of the char generated in the process, the differences in carbon capture efficiency and char conversion with $\phi$ would 
be expected to be even lower than those recorded with coal. However, a higher $\phi$ value would also represent a higher amount of oxygen available in the fuel reactor bed to burn the gases generated during devolatilization/gasification and this would contribute to achieving lower oxygen demands. Figure 5 shows carbon capture efficiency $\left(\eta_{C C}\right)$, char conversion $\left(X_{\text {char }}\right)$, total oxygen demand $\left(\Omega_{T}\right)$, and mean residence time of the iron ore particles in the fuel reactor for different oxygen carrier to fuel ratios $(\phi)$ in experiments with pine wood at $\mathrm{T}_{\mathrm{FR}}=890^{\circ} \mathrm{C}$. Although the mean residence time varied between 8 and 2.2 minutes, no significant changes were observed for $\phi$ greater than unity in either carbon capture efficiency or char conversion. Oxygen demand decreased slightly from 12.4 to $10.6 \%$. Therefore, some different alternatives to a high solids inventory should be investigated in order to reduce the total oxygen demand. One of these alternatives is evaluated in section 3.5.

\subsection{Characterization of the used iron ore}

The iron ore particles experienced $78 \mathrm{~h}$ of continuous hot fluidization during the tests using biomass as fuel. No fluidization or agglomeration problems were detected at any time. Fine particles were collected from the downstream filters of both fuel and air reactors so that the attrition rate of this material could be estimated. The attrition rate was calculated as the mass percentage of particles with a size smaller than $40 \mu \mathrm{m}$ lost per hour of operation. Particles smaller than $45 \mu \mathrm{m}$ were defined as fines not recovered by high efficiency cyclones (Lyngfelt and Thunman, 2005).The attrition rate calculated for the iron ore particles was $0.1 \% / \mathrm{h}$. This value corresponded to a particle lifetime of $1000 \mathrm{~h}$. After the operation in the CLC system, the crushing strength of the iron ore particles also decreased. Nevertheless, this value was still high enough to enable the particles to be used in fluidized bed applications. The additional advantage of this 
material, as well as other Fe-based oxygen carriers proposed for the CLC of solid fuels, is that it is readily available at low cost.

After the experiments, the iron ore particles were characterized in order to study possible morphological or chemical changes. Table 2 summarizes the characteristics of the fresh and used iron ore particles. The iron content of the oxygen carrier in the CLC system and in the fines collected during operation was determined in experiments in a TGA using $15 \% \mathrm{H}_{2}$ at $950^{\circ} \mathrm{C}$. In both cases $76 \% \mathrm{Fe}_{2} \mathrm{O}_{3}$ was found. Nevertheless, it seemed that the $\mathrm{CaO}$ and $\mathrm{MgO}$ initially present in the sample were lost during CLC operation as the analysis of the fines revealed the presence of $\mathrm{CaO}$ and $\mathrm{MgO}$. According to Table 2, the skeletal density and BET area did not experience significant changes. Analysis was also made of the ash deposition on the iron ore particles. The biomass ashes contained significant quantities of alkali metal compounds, which could cause bed sintering and agglomeration, and therefore loss of fluidization in the CLC system. Table 1 shows the composition of the ash from pine sawdust. One of the major components was calcium. Phosphorus, manganese, potassium and magnesium were also present in significant fractions although total amounts were very low because the ash content was $0.4 \%$. During the observation of the iron ore particles using SEM-EDX, qualitative analyses were conducted on the surface of the particles in order to test for the presence of any of these elements. The iron ore particles originally contained $\mathrm{Fe}, \mathrm{Ca}$ and $\mathrm{Mg}$. Therefore, if any ash had been deposited on the surface, elements such as K, Mn or P should be detected. This was not the case in any of the tests performed. Therefore, no evidence was found of ash deposition on the oxygen carrier particles. 


\subsection{Improvement of the CLC process with biomass}

From the aforementioned results, it can be concluded that the main problem in CLC combustion of biomass is the incomplete combustion of the gases generated in the fuel reactor which leads to high oxygen demand. Different alternatives in order to improve combustion of the unburned compounds have been recently presented. One of the most attracting possibilities to burn the gases leaving the fuel reactor is the implementation of a second step in the fuel reactor (Gayán et al., 2013), as shown in Figure 6. This second fuel reactor would be fed by the gases leaving the first fuel reactor. The contact between the unburned gases and the oxygen carrier would be better in this case, as they would be introduced at the bottom of the reactor. A simplified model proposed by Abad et al. (2007a) can give an initial estimation of the mass of solids in the second fuel reactor needed to complete the combustion of the unburned compounds per $\mathrm{MW}_{\text {th }}$ of biomass fed, $m_{O C}$ :

$$
m_{O C}=\eta_{C} \frac{2 d_{a v} M_{O}}{L H V} \frac{\partial}{\Phi R_{O C}\left(\left.\frac{d X_{i}}{d t}\right|_{X_{i}=0}\right)_{a v}} \cdot \frac{\sum F_{i}}{\dot{m}_{S F}}
$$

To simplify the calculations, a number of assumptions were made. No limitations for solids circulation between fuel and air reactor were assumed. The average reactivity $\left(\left.\frac{d X_{i}}{d t}\right|_{X_{i}=0}\right)_{a v}$ for the gas mixture entering the second fuel reactor was estimated as a weighted mean of the average reactivity determined for each gas $\left(\mathrm{CO}, \mathrm{H}_{2}\right.$ and $\left.\mathrm{CH}_{4}\right)$ at the corresponding average gas concentration in the fuel reactor. To calculate the average concentration in the second fuel reactor, the value of the concentration of the different gases at the outlet of this reactor is needed (Johansson et al., 2006). Therefore it was considered that only $0.1 \%$ of the total thermal power in the biomass fed was released as 
unburned at the outlet of the second fuel reactor, i.e. $99.9 \%$ energetic efficiency during combustion was reached. In the absence of energy integration of the fuel and air reactors, the temperature in the second fuel reactor was set to $950^{\circ} \mathrm{C}$, as only reactivity data were available at this temperature. All the calculations were performed considering a reaction order for the gas-solid reaction equal to one.

The minimum solids inventory needed in the second fuel reactor depended on the composition of the gas leaving the first fuel reactor, which in turn depended on the temperature in the first fuel reactor. In this case, the minimum solids inventory needed in the second fuel reactor was $90-140 \mathrm{~kg} / \mathrm{MW}_{\text {th }}$ biomass. Note that these inventories were calculated with no restrictions, so that an order of magnitude could be obtained. The real solids inventories needed should be around 2-10 times those estimated with this model (Abad et al. 2010). The total inventory for the process with both fuel reactors should consider the inventory in the first fuel reactor obtained from the experimental results, which was around $1550 \mathrm{~kg} / \mathrm{MW}_{\text {th }}$ in the temperature range tested $880-915^{\circ} \mathrm{C}$. According to these results, the addition of a second fuel reactor could be an interesting option. Most of the char would be gasified in the first fuel reactor and then the unburned compounds could be sent to the second fuel reactor.

\section{Conclusions}

Chemical looping combustion of biomass was studied in a $500 \mathrm{~W}_{\text {th }}$ unit using a $\mathrm{Fe}_{2} \mathrm{O}_{3^{-}}$ based mineral and pine sawdust. The main combustion products were $\mathrm{CO}_{2}$ and steam. $\mathrm{CO}, \mathrm{H}_{2}$ and $\mathrm{CH}_{4}$ were detected as unburned compounds, but there were no $\mathrm{C}_{2}-\mathrm{C}_{4}$ hydrocarbons. Tars were also collected, mostly naphthalene, but their presence decreased at high fuel reactor temperatures. High carbon capture efficiencies were 
obtained in the $880-915^{\circ} \mathrm{C}$ temperature range both using steam and $\mathrm{CO}_{2}$ as gasifying agents, so recirculated $\mathrm{CO}_{2}$ could be used without reducing efficiency. After $78 \mathrm{~h}$ of continuous hot fluidization, no alkali deposition from biomass ashes was observed.

\section{Acknowledgments}

The authors would like to thank the Spanish Ministry for Science and Innovation for financial support received via the ENE2011-26354 project. This work was also partially supported by the European Commission, under the RFCS program (ACCLAIM Project, Contract RFCP-CT-2012-406). T. Mendiara acknowledges the "Juan de la Cierva" postdoctoral contract awarded by this Ministry. The authors also thank PROMINDSA for providing the iron ore used in this work. 


\section{Bibliography}

Abad, A., Adánez, J., García-Labiano, F., de Diego, L.F., Gayán, P., Celaya, J., 2007a. Mapping of the range of operational conditions for $\mathrm{Cu}-, \mathrm{Fe}-$, and $\mathrm{Ni}$-based oxygen carriers in chemical-looping combustion. Chem. Eng. Sci. 62, 533-549.

Abad, A., García-Labiano, F., de Diego, L.F., Gayán, P., Adánez, J., 2007b. Reduction kinetics of $\mathrm{Cu}-, \mathrm{Ni}-$, and $\mathrm{Fe}$-based oxygen carriers using syngas $\left(\mathrm{CO}+\mathrm{H}_{2}\right)$ for chemical looping combustion. Energy Fuels 21, 1843-1853.

Abad, A., Adánez, J., García-Labiano, F., de Diego, L.F., Gayán, P., 2010. Modeling of the chemical-looping combustion of methane using a $\mathrm{Cu}$-based oxygen-carrier. Combust. Flame 157, 602-615.

Abad, A., Adánez-Rubio, I., Gayán, P., García-Labiano, F., de Diego, L.F., Adánez, J., 2012. Demonstration of chemical-looping with oxygen uncoupling (CLOU) process in a $1.5 \mathrm{~kW}_{\text {th }}$ continuously operating unit using a Cu-based oxygen carrier. Int. J.

Greenhouse Gas Control 16, 189-200.

Abad, A., Gayán, P., de Diego, L.F., García-Labiano, F., Adánez, J., 2013. Fuel reactor modelling in chemical-looping combustion of coal: 1. model formulation. Chem. Eng. Sci. 87, 277-293.

Adánez, J., Abad, A., García-Labiano, F., Gayán, P., de Diego, L.F., 2012. Progress in Chemical-Looping Combustion and Reforming Technologies. A review. Prog. Energ. Combust. 38, 215-282.

Bridgwater, A.V., 1995. The technical and economic feasibility of biomass gasification for power generation. Fuel 74, 631-653

Cao, Y., Pan, W.P. Investigation of Chemical Looping Combustion by Solid Fuels. 1. Process Analysis. 2006. Energy Fuels 20, 836-844. 
Cuadrat, A., Abad, A., García-Labiano, F., Gayán, P., de Diego, L.F., Adánez, J., 2011. The use of ilmenite as oxygen-carrier in a $500 \mathrm{~W}_{\text {th }}$ chemical-looping coal combustion unit, Int. J. Greenhouse Gas Control 5, 1630-1642.

Cuadrat, A., Abad, A., García-Labiano F., Gayán, P., de Diego, L.F., Adánez, J., 2012. Relevance of the coal rank on the performance of the in situ gasification chemicallooping combustion. Chem Eng J 195-196, 91-102.

Diebold, J., Elliot, D.C., Bridgwater, A.V., Solanstausta, Y., Beckman, D., 1994. Assessment of liquefaction and pyrolysis systems. VTT on behalf of the IEA Bionergy agreement.

Ekström, C.; Schwendig, F.; Biede, O.; Franco, F.; Haupt, G.; de Koeijer, G.; Papapavlou, C.; Røkke, P.E, 2009. Techno-economic evaluations and benchmarking of pre-combustion $\mathrm{CO}_{2}$ capture and oxy-fuel processes developed in the european ENCAP project. Energ Procedia 1, 4233-4240.

Evans, R.J., Milne, T.A., 1987a. Molecular characterization of the pyrolysis of biomass. 1. Fundamentals. Energy Fuels 1, 123-138.

Evans, R.J., Milne, T.A., 1987b. Molecular characterization of the pyrolysis of biomass. 2. Applications. Energy Fuels 1, 311-319.

Gayán, P., Abad, A., de Diego, L.F., García-Labiano, F., Adánez, J., 2013. Assessment of technological solutions for improving Chemical Looping Combustion of solid fuels with $\mathrm{CO}_{2}$ capture. http://dx.doi.org/10.1016/j.cej.2013.08.004

Gu, H., Sheng, L., Xiao, J., Zhang, S., Song, T., 2011. Chemical looping combustion of biomass/coal with natural iron ore as oxygen carrier in a continuous reactor. Energy Fuels 25, 446-455. 
IPCC. IPCC special report on Carbon Capture and Storage. Cambridge, UK: Cambridge University Press; 2005.

Jerndal, E., Leion, H., Axelsson, L., Ekvall, T., Hedberg, M., Johansson et al. 2011.

Using low-cost iron-based materials as oxygen carriers for chemical looping

combustion. Oil \& Gas Sci. Technol. 66, 235-248.

Johansson, M., Mattisson, T., Lyngfelt, A., 2006. Comparison of oxygen carriers for chemical-looping combustion. Therm. Sci. 10, 93-107.

Kempkes, V., Kather, A., 2012. Chemical Looping Combustion: comparative analysis of two different overall process configurations for removing unburnt gaseous components. Proceedings from the $2^{\text {nd }}$ International Conference on Chemical Looping, 26-28 September, Darmstadt, Germany.

Kolbitsch, P., Pröll, T., Bolhar-Nordenkampf, J., Hofbauer, H. 2009. Operating experience with chemical looping combustion in a $120 \mathrm{~kW}$ dual fluidized bed (DCFB) unit. Energy Procedia 1, 1465-1472.

Kramp, M., Thon, A., Hatge, E.-U., Heinrich, S., Werther, J., 2012. Carbon stripping-a critical process step in chemical looping combustion of solid fuels. Chem. Eng. Technol. 35, 497-507.

Leion, H., Jerndal, E., Steenari, B.-M., Hermansson, S., Israelsson, M., Jansson, E., Johnsson, M., Thunberg, R., Vadenbo, A., Mattisson, T., Lyngfelt, A.,2009. Solid fuels in chemical-looping combustion using oxide scale and unprocessed iron ore as oxygen carriers. Fuel 88, 1945-1954.

Leion, H., Mattisson, T., Lyngfelt, A.,2011. Chemical-looping combustion of solid fuels in a laboratory fluidized-bed reactor. Oil \& Gas Sci. Technol. 66, 201-208. 
Lyngfelt, A., Thunman, H., 2005. Construction and $100 \mathrm{~h}$ of operational experience of a $10 \mathrm{~kW}_{\text {th }}$ chemical-looping combustor, in: Thomas, D.C. (Ed.), Carbon Dioxide Capture for Storage in Deep Geologic Formations - Results from the $\mathrm{CO}_{2}$ Capture Project. Elsevier Ltd., Oxford, pp. 625-645.

Markström P, Linderholm C, Lyngfelt A., 2013. Chemical-looping combustion of solid fuels - Design and operation of a $100 \mathrm{~kW}$ unit with bituminous coal. Int. J. Greenhouse Gas Control 15, 150-162.

Mendiara, T., Pérez, R., Abad, A., de Diego, L.F., García-Labiano, F., Gayán, P., Adánez, J., 2012. Low-cost Fe-based oxygen carrier materials for the iG-CLC process with coal. 1. Ind. Eng. Chem. Res. 51, 16216-16229.

Mendiara, T., de Diego, L.F., García-Labiano, F., Gayán, P., Abad, A., Adánez, J., 2013. Behaviour of a bauxite waste material as oxygen carrier in a $500 \mathrm{~W}_{\text {th }}$ CLC unit with coal. Int. J. Greenhouse Gas Control 17, 170-182.

Milne, T.A., Evans, R.J., Abatzoglou, N., 1998. Biomass gasifier 'tars': their nature, formation and conversion, NREL Report NREL/TP-570-25357, Colorado.

Orth, M., Ströhle, J., Epple, B.,2012. Design and Operation of a 1 MWth Chemical Looping Plant. Proceedings from the $2^{\text {nd }}$ International Conference on Chemical Looping, 26-28 September 2012, Darmstadt, Germany.

Pipitone, G., Bolland, O., 2009. Power generation with $\mathrm{CO}_{2}$ capture: Technology for $\mathrm{CO}_{2}$ purification. Int. J. Greenhouse Gas Control 3, 528-534.

Reed, T.B., Levie, B., Graboski, M.S., 1987. Tar Conversion, in: Fundamentals, Development and Scaleup of the Air-Oxygen Stratified Downdraft Gasifier. Solar Energy Research Institute, SERI/PR-234-2571. 
Shen, L., Wu, J., Xiao, J., Song, Q., Xiao, R., 2009. Chemical looping combustion of biomass in a $10 \mathrm{~kW}_{\text {th }}$ reactor with iron oxide as oxygen carrier. Energy Fuels 23,24982505.

Simell, P., Stahlberg, P., Kurkela, E., Albretch, J., Deutch, S., Sjostrom, K., 2000.

Provisional protocol for the sampling and analysis of tar and particulates in the gas from large-scale biomass gasifiers. Version 1998. Biomass Bioenerg. 18, 19-38.

Virginie, M., Adánez, J., Courson, C., de Diego, L.F., García-Labiano, F., Niznansky, D., Kiennemann, A., Gayán, P., Abad, A., 2012. Effect of Fe-olivine on the tar content during biomass gasification in a dual fluidized bed. Appl. Catal. B-Environ. 121-122, 214-222 


\section{Nomenclature}

$C_{\text {char, elutr: }}$ carbon in elutriated particles $(\mathrm{kg} / \mathrm{s})$

$C_{\text {char, } A R}$ : carbon flow from char to the air reactor $(\mathrm{kg} / \mathrm{s})$

$d_{a v}:$ average stochiometric factor $(\mathrm{mol} \mathrm{O} 2 / \mathrm{mol}$ fuel $)$

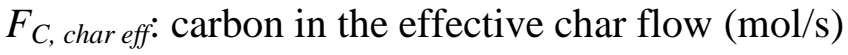

$F_{\mathrm{CO}_{2}, \mathrm{AR}}$ : carbon dioxide molar flow in the air reactor $(\mathrm{mol} / \mathrm{s})$

$F_{C, \text { vol }}$ : carbon flow from volatile matter $(\mathrm{mol} / \mathrm{s})$

$F_{C_{x} H_{y} O_{z}}:$ molar flow of tar at the outlet of the fuel reactor $(\mathrm{mol} / \mathrm{s})$

$F_{i, F R}: i$ species molar flow in the fuel reactor inlet/outlet stream (mol/s)

$F_{O C}:$ solid circulation rate $(\mathrm{kg} / \mathrm{s})$

$m_{\text {char, } F R}:$ mass of char in the fuel reactor $(\mathrm{kg} / \mathrm{s})$

$M_{O}$ : molecular weight of oxygen $(\mathrm{kg} / \mathrm{mol})$

$m_{O C}:$ solids inventory, $\mathrm{kg}$ per $\mathrm{MW}_{\text {th }}$

$m_{O C, F R}:$ mass of oxygen carrier in the fuel reactor $(\mathrm{kg})$

$\dot{m}_{S F}$ : biomass mass flow $(\mathrm{kg} / \mathrm{s})$

$\mathrm{O}_{2 \text { demand, biomass }}$ : oxygen flow needed to completely burn the fuel (mol/s)

$\left(-r_{c}\right)$ : instantaneous rate of char conversion $\left(\mathrm{s}^{-1}\right)$

$R_{O C}:$ oxygen transport capacity

$t_{m, O C}:$ mean residence time of the oxygen carrier in the fuel reactor (s)

$t_{m, \text { char }}$ : mean residence time of char in the fuel reactor (s)

$X_{\text {char }}:$ char conversion

$X_{i}$ : oxygen carrier conversion in the $i$ reaction

$\delta:$ constant parameter (Abad et al., 2007b)

$\phi:$ oxygen carrier to fuel ratio 
$\Omega_{S F}$ : oxygen necessary to burn the solid fuel ( $\mathrm{kg}$ oxygen $/ \mathrm{kg}$ biomass. $\mathrm{s}$ )

$\Omega_{T}$ : total oxygen demand

$\eta_{C}:$ combustion efficiency in the second fuel reactor

$\eta_{C C}:$ carbon capture efficiency

$\Phi$ : characteristic reactivity in the reactor

$L H V$ : low heating value $(\mathrm{MJ} / \mathrm{kg})$ 


\section{List of Figure Captions}

Figure 1. In situ Gasification Chemical Looping Combustion process

Figure 2. Experimental unit ICB-CSIC-s1

Figure 3. (A) $\mathrm{CO}_{2}, \mathrm{CO}, \mathrm{H}_{2}, \mathrm{CH}_{4}$ (dry $\mathrm{N}_{2}$ free basis) and tar content (B) Tar composition at the fuel reactor outlet in experiments with pine wood as fuel at different fuel reactor temperatures $\left(\mathrm{T}_{\mathrm{FR}}\right)$. Conditions: $\phi=1$

Figure 4. (A) Carbon capture efficiency $\left(\eta_{C C}\right)$, char conversion $\left(X_{\text {char }}\right)$, combustion efficiency in the fuel reactor $\left(\eta_{\text {Comb,FR }}\right)$ and oxygen demand $\left(\Omega_{\mathrm{T}}\right)(\mathrm{B})$ Rate of char conversion in experiments with different oxygen carriers and fuels at different fuel reactor temperatures $\left(\mathrm{T}_{\mathrm{FR}}\right)$. Conditions: $\phi=1$

Figure 5. Carbon capture efficiency $\left(\eta_{C C}\right)$, char conversion $\left(X_{c h a r}\right)$, oxygen demand $\left(\Omega_{T}\right)$ and mean residence time of the iron ore particles in the fuel reactor for different oxygen carrier to fuel ratios $(\phi)$ in experiments with pine wood at $\mathrm{T}_{\mathrm{FR}}=890^{\circ} \mathrm{C}$

Figure 6. Scheme of a CLC unit incorporation a second fuel reactor to burn the gases leaving the fuel reactor (Gayán et al., 2013). OC: oxygen carrier 


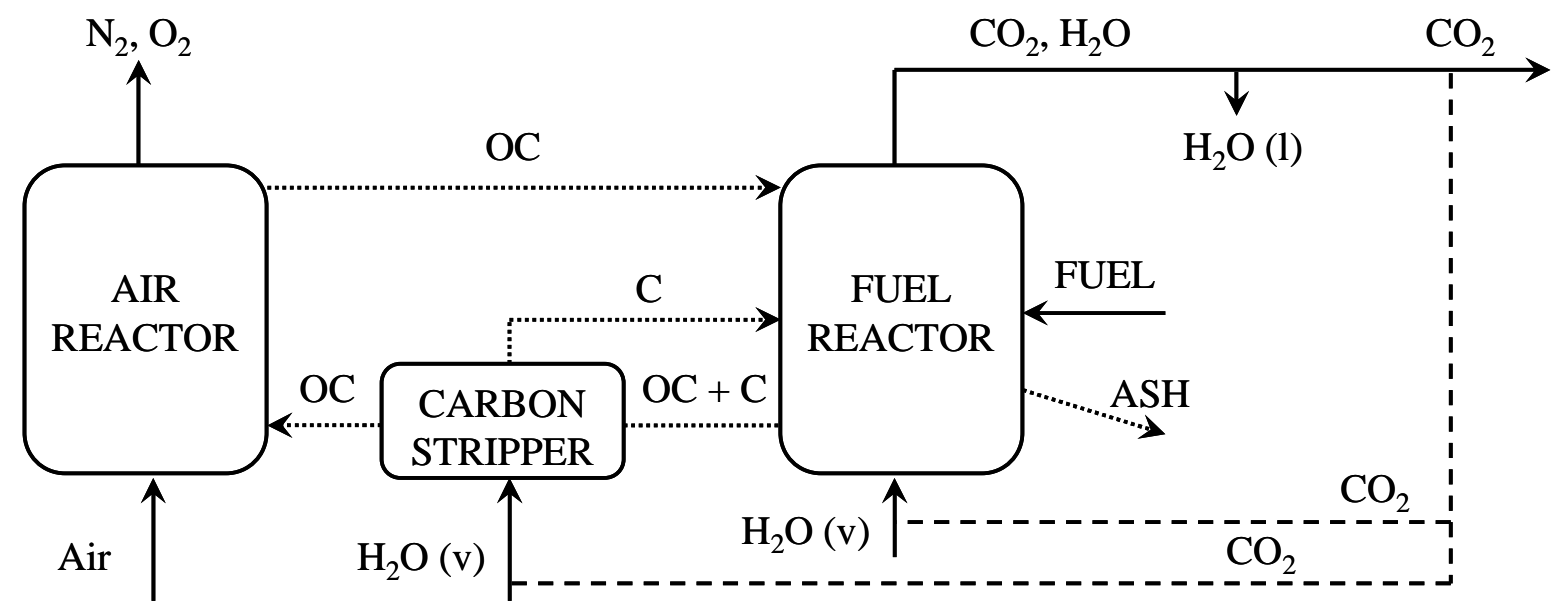

Figure 1. 


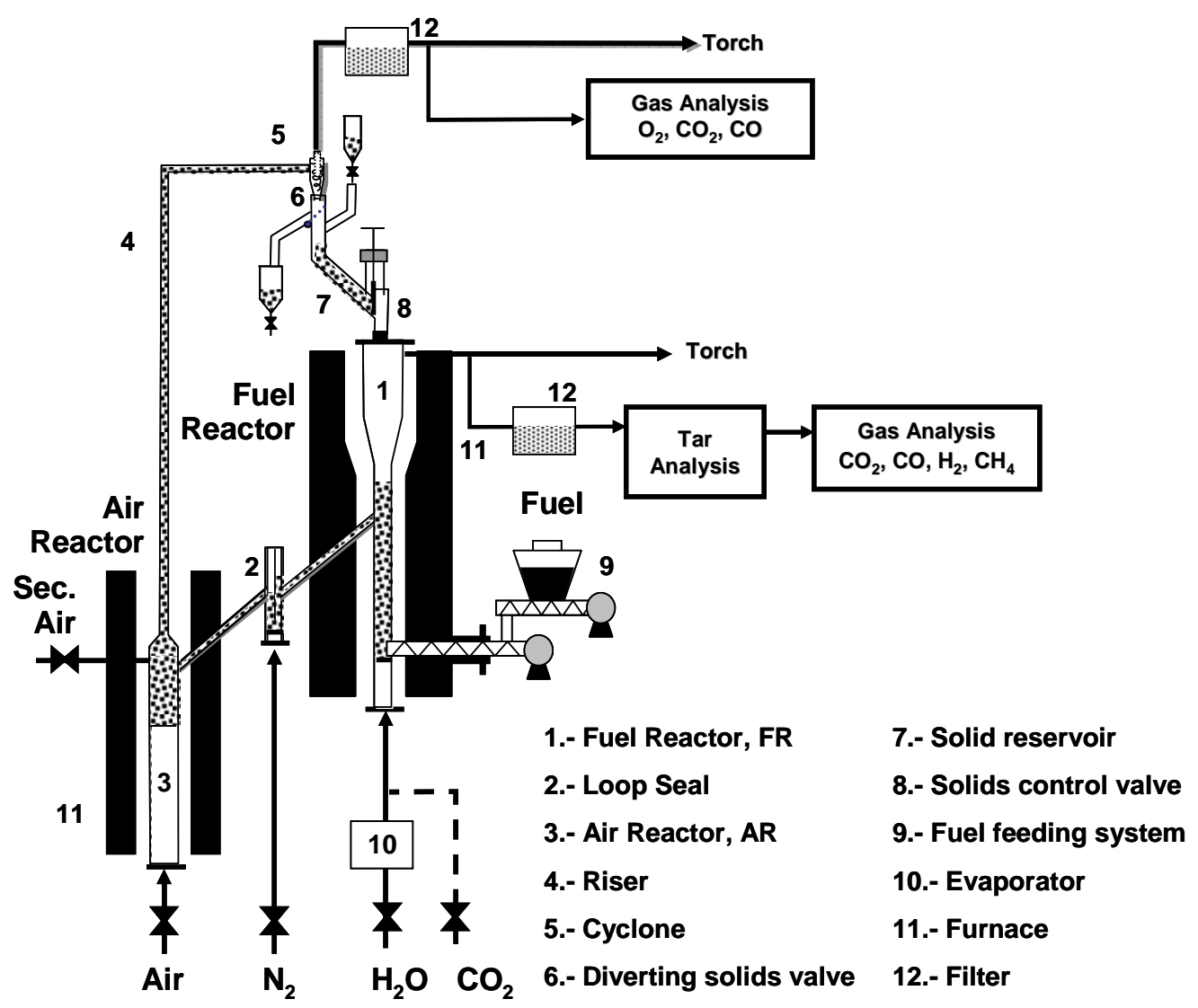

Figure 2. 

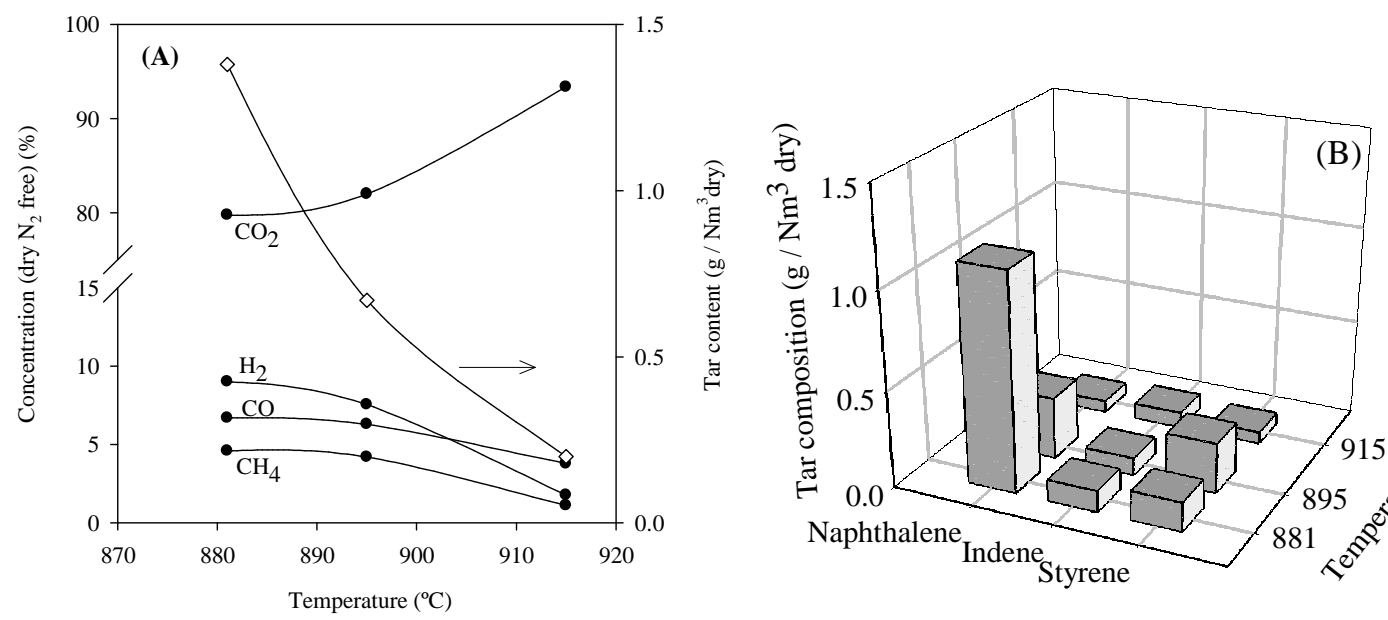

Figure 3. 

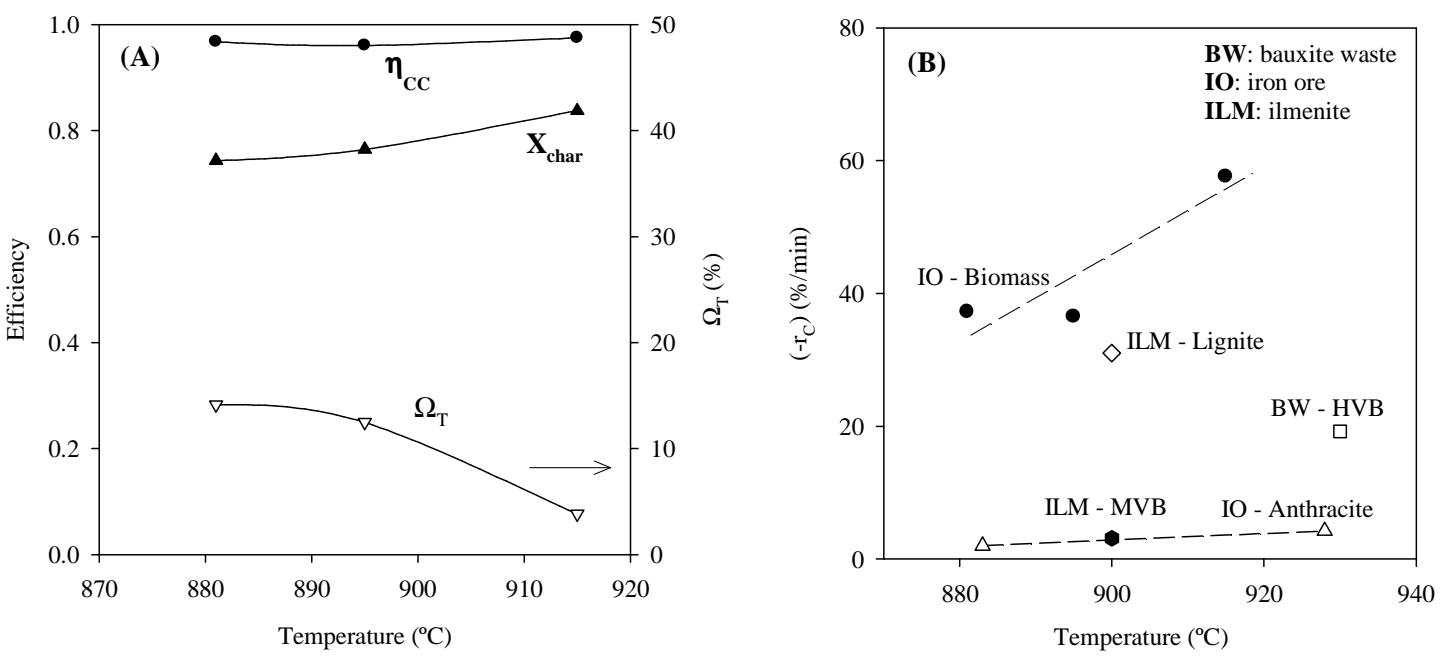

Figure 4. 


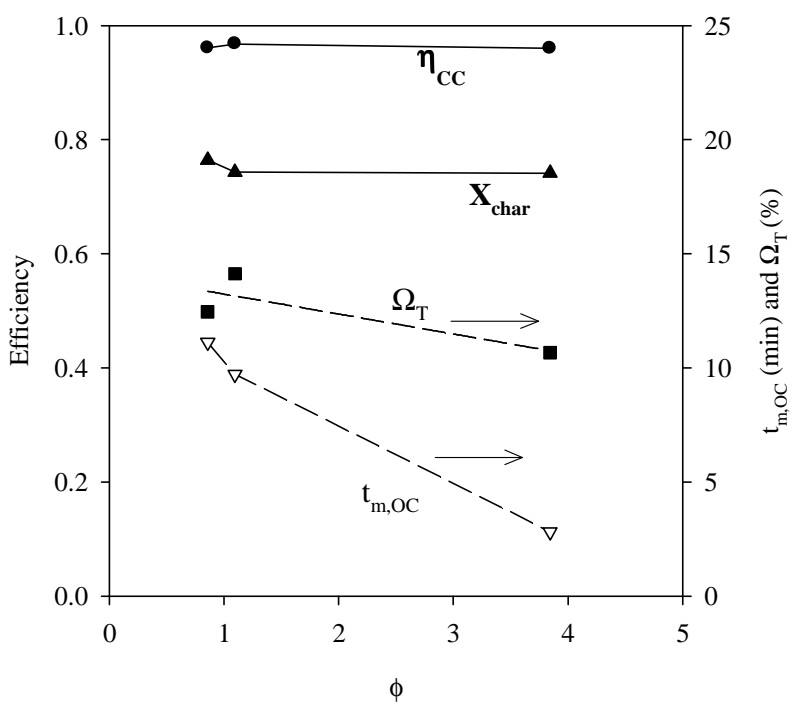

Figure 5. 


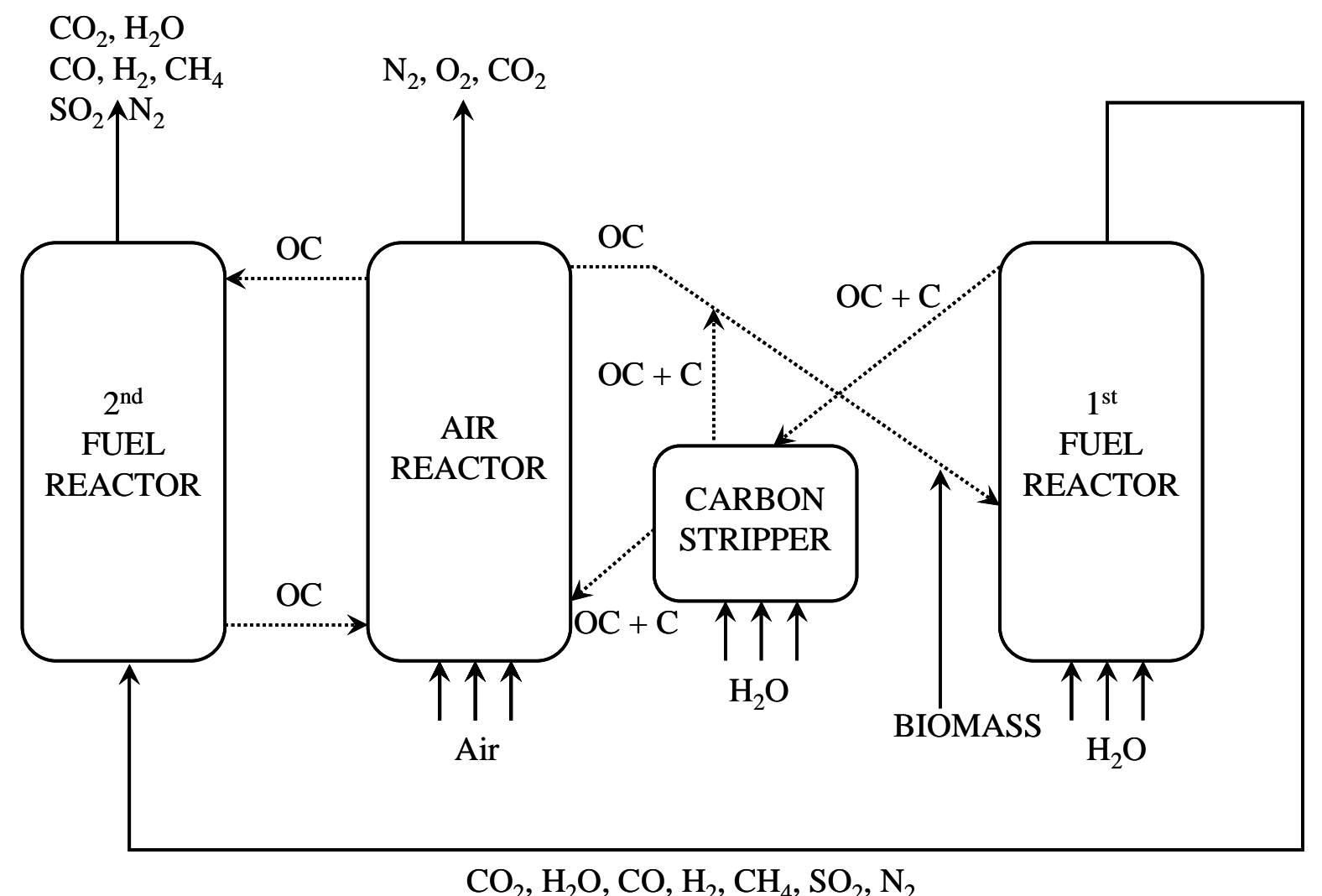

Figure 6. 


\section{Tables}

Table 1. Proximate and ultimate analyses of biomass, including ash composition (\% wt)

\section{Ultimate analysis Proximate analysis}

$\begin{array}{llll}\text { Carbon } & 51.3 & \text { Moisture } & 4.2 \\ \text { Hydrogen } & 6.0 & \text { Ash } & 0.4 \\ \text { Nitrogen } & 0.3 & \text { Volatile matter } & 81.0 \\ \text { Sulphur } & 0 & \text { Fixed carbon } & 14.4 \\ \text { Oxygen } & 38.3 & & \end{array}$

\section{Ash composition}

\begin{tabular}{llll}
\hline $\mathrm{Al}_{2} \mathrm{O}_{3}$ & 2.4 & $\mathrm{Na}_{2} \mathrm{O}$ & 0.2 \\
$\mathrm{CaO}$ & 40.7 & $\mathrm{SiO}_{2}$ & 6.6 \\
$\mathrm{Fe}_{2} \mathrm{O}_{3}$ & 1.3 & $\mathrm{TiO}_{2}$ & 0.1 \\
$\mathrm{~K}_{2} \mathrm{O}$ & 8.9 & $\mathrm{MnO}_{2}$ & 0.8 \\
$\mathrm{MgO}$ & 6.6 & $\mathrm{P}_{2} \mathrm{O}_{5}$ & 1.6 \\
\hline $\mathrm{LHV}(\mathrm{kJ} / \mathrm{kg})$ & & 19140 & \\
\hline
\end{tabular}


Table 2. Characterization of the mineral based on hematite (fresh and used in the CLC unit)

\begin{tabular}{lll} 
& Calcined & Used $^{\mathrm{c}}$ \\
\hline $\mathrm{Fe}_{2} \mathrm{O}_{3}(\%$ wt) & $76^{\mathrm{a}}$ & $76^{\mathrm{a}}$ \\
XRD main phases & $\mathrm{Fe}_{2} \mathrm{O}_{3}, \mathrm{SiO}_{2}, \mathrm{CaO}, \mathrm{MgO}$ & $\mathrm{Fe}_{2} \mathrm{O}_{3}, \mathrm{SiO}_{2}$ \\
Crushing strength (N) & 3.1 & 2.3 \\
Oxygen transport capacity, $R_{O C},(\%)^{\mathrm{b}}$ & 2.5 & 2.5 \\
Porosity (\%) & 33.3 & 16.9 \\
Skeletal density $\left(\mathrm{kg} / \mathrm{m}^{3}\right)$ & 4462 & 4217 \\
Specific surface area, BET $\left(\mathrm{m}^{2} / \mathrm{g}\right)$ & 1.1 & 0.5 \\
\hline
\end{tabular}

${ }^{a}$ Determined by TGA

${ }^{\mathrm{b}} R_{O C}=\frac{m_{o}-m_{r}}{m_{o}}$

${ }^{c}$ After 78 hours of continuous fluidization 